\title{
Molecular imaging of rheumatoid arthritis by radiolabelled monoclonal antibodies: new imaging strategies to guide molecular therapies
}

\author{
G. Malviya - F. Conti • M. Chianelli • F. Scopinaro • \\ R. A. Dierckx • A. Signore
}

Received: 11 August 2009 / Accepted: 25 August 2009/Published online: 24 September 2009

(C) The Author(s) 2009. This article is published with open access at Springerlink.com

\begin{abstract}
The closing of the last century opened a wide variety of approaches for inflammation imaging and treatment of patients with rheumatoid arthritis (RA). The introduction of biological therapies for the management of RA started a revolution in the therapeutic armamentarium with the development of several novel monoclonal antibodies (mAbs), which can be murine, chimeric, humanised and fully human antibodies. Monoclonal antibodies specifically bind to their target, which could be adhesion molecules, activation markers, antigens or receptors, to interfere with specific inflammation pathways at the molecular level, leading to immune-modulation of the underlying pathogenic process. These new generation of mAbs can also be radiolabelled by using direct or indirect method, with a variety of nuclides, depending upon the specific diagnostic application. For studying rheumatoid arthritis patients, several monoclonal antibodies and their fragments, including anti-TNF- $\alpha$, anti-
\end{abstract}

G. Malviya $\cdot$ M. Chianelli $\cdot$ R. A. Dierckx $\cdot$ A. Signore

Department of Nuclear Medicine and Molecular Imaging,

University Medical Centre Groningen, University of Groningen,

Groningen, The Netherlands

F. Conti

Rheumatology Unit, I Faculty of Medicine and Surgery,

"Sapienza" University of Rome,

Rome, Italy

M. Chianelli

Unit of Nuclear Medicine, Regina apostolorum Hospital,

Albano, Rome, Italy

F. Scopinaro $\cdot$ A. Signore $(\bowtie)$

Nuclear Medicine Department, "Sapienza" University of Rome,

St. Andrea Hospital, Via di Grottarossa 1035,

00189 Rome, Italy

e-mail: alberto.signore@uniroma1.it
CD20, anti-CD3, anti-CD4 and anti-E-selectin antibody, have been radiolabelled mainly with ${ }^{99 \mathrm{~m}} \mathrm{Tc}$ or ${ }^{111} \mathrm{In}$. Scintigraphy with these radiolabelled antibodies may offer an exciting possibility for the study of RA patients and holds two types of information: (1) it allows better staging of the disease and diagnosis of the state of activity by early detection of inflamed joints that might be difficult to assess; (2) it might provide a possibility to perform 'evidence-based biological therapy' of arthritis with a view to assessing whether an antibody will localise in an inflamed joint before using the same unlabelled antibody therapeutically. This might prove particularly important for the selection of patients to be treated since biological therapies can be associated with severe side-effects and are considerably expensive. This article reviews the use of radiolabelled mAbs in the study of RA with particular emphasis on the use of different radiolabelled monoclonal antibodies for therapy decision-making and follow-up.

Keywords Monoclonal antibodies · Rheumatoid arthritis · Molecular imaging · Biological therapies .

Therapy decision-making

\section{New molecular therapies for rheumatoid arthritis}

Rheumatoid arthritis (RA) is a chronic inflammatory autoimmune disease of unknown aetiology that leads to progressive joint destruction, functional disability and extra articular complications. RA is a systemic disease that affects many organ systems and is associated with abnormally high rates of other associated diseases including malignancies, infections and cardiovascular diseases [1-5]. The genetic background predisposes to the disease, but also person-related and environmental factors (like age, gender, 
infectious agents, smoking and dietary factors) are thought to play a role in disease pathogenesis. The prevalence of RA globally is around $1 \%$. Recently, it has been shown that $50 \%$ of patients with RA are disabled within 10 years of onset of disease and survival is reduced [6-8]. Over the last decades the strategy of treating RA has changed, and now the mainstays of RA therapy are disease modifying antirheumatic drugs (DMARDs) such as azathioprine, hydroxychloroquine, sulphasalazine, cyclosporin A, leflunomide and methotrexate; the last of these has generally become the standard of care. Many of these medications reduce radiological progression of structural damage [9]. An earlier use of DMARDs reduces the risk of joint damage in future [10]. Several studies demonstrated that an imbalance occurs in cytokine cascade resulting in presence of proinflammatory cytokines in synovium and plasma, which leads to joint inflammation and cartilage destruction characteristic of RA. Attention has therefore been given to develop inhibitors of pro-inflammatory cytokines and their receptors. The clinical management of RA has been revolutionised by introduction of the 'biological agents', including monoclonal antibody, fusion protein and Fab' fragment of monoclonal antibody. These biologicals target pro-inflammatory cytokines (e.g., TNF- $\alpha$, IL-1 and IL-6) and membrane-bound receptors (e.g., CD3 and CD4) for treatment of patients $[11,12]$. This new class of drugs has been termed 'biologic response modifiers'. Nevertheless, treatment with biologicals is expensive, especially in the case of long treatments such as in RA.

A pre-therapy scintigraphic approach with radiolabelled monoclonal antibodies (mAbs) may allow us to evaluate the presence of the target molecules in the inflammatory lesion, thus helping in the selection of the most efficient therapy and predicting therapy response; overall, they may provide a cost-effective solution [13]. Additionally, for scintigraphic purpose, patients receive a tracer (non-pharmacological) dose of radiolabelled $\mathrm{mAb}$, which does not induce any clinical response or side-effect.

This article will review the use of radiolabelled mAbs in the study of RA (Table 1) with particular emphasis on the use of different radiolabelled monoclonal antibodies for therapy decision-making and follow-up.
Human antibodies

Antibodies are composed by light $(\mathrm{L})$ and heavy $(\mathrm{H})$ chains. These chains are covalently linked via interchain disulfide (S-S) bonds between Cysteine residues and by non-covalent interactions such as hydrogen bonding, hydrophobic interactions and salt linkage. Similar non-covalent interactions and disulphide bridges have also been linked to two identical $\mathrm{H}$ and $\mathrm{L}$ chain combinations to each other, forming the basic four-chain $(\mathrm{H}-\mathrm{L})_{2}$ structure of an antibody. Each antibody has either kappa ( $\kappa)$ or lambda ( $\lambda$ ) L chains. Different antibody isotypes IgA, IgG, IgD, $\operatorname{IgE}$ and $\operatorname{IgM}$ are named according to their $\mathrm{H}$ chain types $(\alpha, \gamma, \delta, \varepsilon$ or $\mu)$, which influences the effecter functions of the antibody molecules. IgG are most frequent monoclonal antibodies and have a Y-shaped structure with a molecular weight of approximately 150,000 Daltons (Da).

\section{Therapeutic antibodies}

In 1975, Kohler and Milstein first reported production of murine monoclonal antibodies using hybridoma technology [14], and by $1980 \mathrm{mAbs}$ were already involved in the human studies. OKT3 (Orthoclone, Muromonab) is one of the first drug in the class of monoclonal antibodies indicated for the treatment of autoimmune diseases. Murine monoclonal antibodies are $100 \%$ murine protein therefore they can induce several major side-effects. Mouse antibodies are recognised as an antigen by the human immune system that generates its own human anti-mouse antibodies (HAMA). These HAMA may inactivate and eliminate murine antibodies after repeated administration [15]. For this reason, therapeutic benefits of murine mAbs could be limited by their side-effect profile and short serum half-life [16]. In 1984, Morrison et al. first demonstrated the production of chimeric antibody composed of mouse antigen-binding domain and human constant region domain [17]. A chimeric monoclonal antibody is a combination of mouse and human gene sequences, roughly 25 and $75 \%$, respectively. These mAbs had minimized immunogenic content, triggered the immunologic efficiency and allowed a prolonged serum half-life in comparison with murine

Table 1 Molecular imaging of rheumatoid arthritis by radiolabelled mAbs

\begin{tabular}{|c|c|c|c|c|c|c|}
\hline Monoclonal antibody & Company & Type & Class & Isotope & Target & Ref. \\
\hline Infliximab (Remicade) & Centocor, Inc. & Chimeric & IgG1 & ${ }^{99 \mathrm{~m}} \mathrm{Tc}$ & TNF- $\alpha$ & $13,34,35$ \\
\hline Adalimumab (Humira) & Abbott Labs & Fully human & IgG1 & ${ }^{99 \mathrm{~m}} \mathrm{Tc}$ & TNF- $\alpha$ & 40,41 \\
\hline Rituximab (Rituxan/Mabthera) & Genentech/Roche & Chimeric & IgG1 & ${ }^{99 \mathrm{~m}} \mathrm{Tc}$ & $\mathrm{CD} 20$ & $49,51,52$ \\
\hline MAX.16H5 & - & Murine & IgG1 & ${ }^{99 \mathrm{~m}} \mathrm{Tc}$ & $\mathrm{CD} 4$ & $57-59$ \\
\hline $1.2 \mathrm{~B} 6$ & - & Murine & IgG1 & ${ }^{111}$ In & E-selectin & $67-69,73,74$ \\
\hline OKT-3 (Muromonab) & Ortho Pharma & Murine & IgG2 & ${ }^{99 \mathrm{~m}} \mathrm{Tc}$ & CD3 & 83,84 \\
\hline
\end{tabular}


mAbs. Chimeric mAbs such as infliximab (Remicade), however, also have problems of triggering human antichimeric antibodies (HACA) response [18, 19], that may reduce the therapeutic benefit and effectiveness of the therapy. In 1986, Jones et al. reported the production of humanised monoclonal antibody that could help to overcome the problems of HAMA and HACA responses discussed above [20, 21]. These genetically engineered humanised mAbs have approximately $95 \%$ of human sequence that results in minimal or no immunogenic response [22]. Fully human antibodies have eventually been produced that contain almost $100 \%$ human protein. The key techniques for the development of fully human mAbs are the phage display technology and genetically engineered mice [23-25]. These antibodies, however, have been considered as 'fully human' in the sense that coding genes do not contain any part from other species. These antibodies are expected to have a lower therapeutic dose and dosing frequency with a better side-effect profile. Fab' fragments have also recently been introduced for the treatment of RA. To obtain a Fab' fragment, the $\mathrm{Fc}$ portion of $\mathrm{mAb}$, which serves to bind various effecter molecules of immune system, is completely removed. Fab' fragments cannot induce, therefore, antibody-dependent cellular cytotoxicity (ADCC) or apoptosis in $\mathrm{T}$ lymphocytes or macrophages compared to complete antibodies [26, 27] and should have, therefore, a better safety profile.

\section{New imaging strategies as a guide to molecular therapies}

Several monoclonal antibodies have been radiolabelled for diagnostic purposes in patients with RA and in particular for therapy decision-making and follow-up. These are reported below.

\section{Anti-TNF- $\alpha$ monoclonal antibody (infliximab)}

In August of 1998, the United States Food and Drug Administration (FDA) approved infliximab (Remicade) for the treatment of moderate to severe active rheumatoid arthritis. Infliximab is a chimeric $\operatorname{IgG} 1 \kappa \mathrm{mAb}$ with a murine variable $(\mathrm{Fv})$ domain of mouse anti-human TNF- $\alpha$ antibody and constant $(\mathrm{Fc})$ sequences of human $\mathrm{IgG}$. It is produced by recombinant cell culture technique. Infliximab specifically targets and binds with both soluble and membrane-bound TNF- $\alpha$ with high avidity and affinity $\left(\mathrm{Kd}=10^{10} \mathrm{M}^{-1}\right)$ and forms a stable non-dissociating immune complex [28]. This binding neutralizes the biological activity of TNF- $\alpha$ by inhibiting the binding of TNF- $\alpha$ to its receptor [29]. Infliximab does not neutralize TNF- $\beta$ (lymphotoxin $\alpha$ ). Infliximab has a median terminal half-life of 9.5 days. In brief, TNF- $\alpha$ induces the pro-inflammatory cytokines (such as IL-1 and IL-6) and acute-phase reactants, activates the function of eosinophils and neutrophils, and enhances the migration of leukocytes by increasing permeability of endothelial layer along with the expression of adhesion molecules in synovitis [30]. Studies have been demonstrated that infliximab may induce cell lysis in transmembrane TNF- $\alpha$ expressing cells in vitro [29] and in vivo [31], mediated by ADCC or complementdependent cytotoxicity (CDA) $[32,33]$.

\section{Molecular imaging with ${ }^{99 m} T c$-anti-TNF- $\alpha$ mAb (infliximab)}

Infliximab was radiolabelled with ${ }^{99 \mathrm{~m}} \mathrm{Tc}$ using direct radiolabelling method [34]. In brief, disulfide bridges present in $\mathrm{mAb}$ were reduced by 2-mercaptoethanol (2-ME) and radiolabelling of activated $\mathrm{mAb}$ was performed by using methylene diphosphonic acid (MDP), as a weak competitive ligand. By using this method, a high labelling efficiency (LE) of more than $97 \%$ was achieved.

Conti et al. successfully performed a scintigraphic study in a patient with arthritis to assess the degree of TNF- $\alpha$ mediated inflammation in the affected knee [35]. The patient underwent scintigraphic examination with ${ }^{99 \mathrm{~m}} \mathrm{Tc}$-labelled infliximab before and 4 months after the intra-articular infliximab therapy. After injection of ${ }^{99 \mathrm{~m}} \mathrm{Tc}$-infliximab (555 MBq), planner images of the inflamed joint were acquired at 6 and $24 \mathrm{~h}$. Scintigraphy showed intense accumulation of ${ }^{99 \mathrm{~m}} \mathrm{Tc}$-infliximab in the affected knee that represents the presence of high level of intra-lesional TNF- $\alpha$. Interestingly, 4 months after the intra-articular infliximab therapy, there was no uptake found in the inflamed joint (Fig. 1). Clinical parameters including visual analogue scale (VAS), erythrocyte sedimentation rate (ESR) and C-reactive protein (CRP) level confirmed the complete remission of the patient.

A pilot study was performed in seven RA patients (nine inflamed joints) using scintigraphy with ${ }^{99 \mathrm{~m}} \mathrm{Tc}$-infliximab [13]. RA patients underwent 99m-technetium labelled infliximab scintigraphy before and 3 months after the intra-articular infliximab therapy. Planar images of arthritic joints were acquired at 3,6 , and $24 \mathrm{~h}$ after $555 \mathrm{MBq}$ $(200 \mu \mathrm{g})$ injection of ${ }^{99 \mathrm{~m}} \mathrm{Tc}$-infliximab. In this study, ${ }^{99 \mathrm{~m}} \mathrm{Tc}-$ infliximab demonstrated very specific uptake in the inflamed joints, whereas normal joints did not show any uptake. Post-treatment scintigraphy examinations demonstrated different amounts of radiopharmaceutical uptake in inflamed joints. Three inflamed joints showed significant changes in uptake whereas in other four joints uptake was only slightly reduced, and it was unchanged in two joints. Clinical improvement of symptoms and reduction of swelling were higher in patients with the higher uptake of 
Fig. 1 Scintigraphy with

${ }^{99 \mathrm{~m}} \mathrm{Tc}$-infliximab before (a) and 4 months after (b) intra-articular administration of infliximab. Red colour represents uptake of the ${ }^{99 \mathrm{~m}}$ Tc-infliximab in scintigraph. (From Conti $\mathrm{F}$ et al. Arthritis Rheum 2005; 52 (4): 1224-1226, with permission)
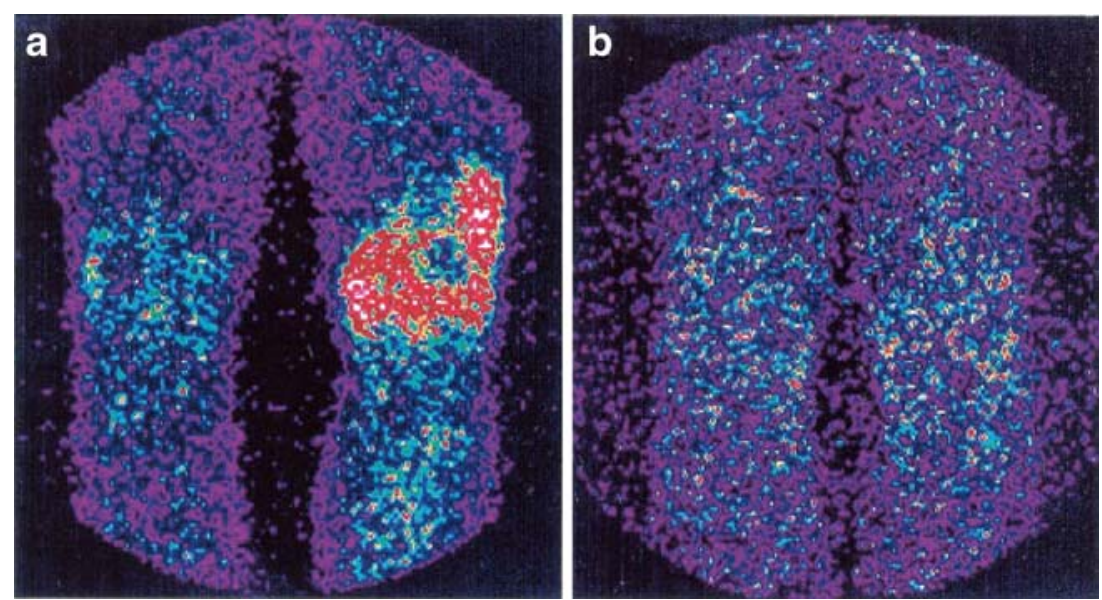

${ }^{99 m}$ Tc-infliximab pre-therapy and decrease of uptake after therapy.

These preliminary studies in humans have demonstrated specific targeting of this radiopharmaceutical in inflamed joints. These studies also showed that the selection of candidates for unlabelled anti-TNF- $\alpha$ therapy and prediction of therapy response could be possible by using ${ }^{99}$ Tc-infliximab scintigraphy. The mechanism of accumulation at the site of inflammation, however, remains speculative until now, and more studies are required to investigate the specific uptake of this radiopharmaceutical. Moreover, these scintigraphic studies have been performed in a very small number of highly selected patients, and therefore need to be analysed in a larger series of patients in multi-centre studies to evaluate the potential use of this technique in a clinical setting.

\section{Anti-TNF- $\alpha$ monoclonal antibody (adalimumab)}

In December of 2002, the FDA approved adalimumab for the management of moderate to severe active rheumatoid arthritis and psoriatic arthritis. As the first 'fully human' antibody against TNF- $\alpha$, adalimumab (Humira) is engineered through phase display technology. Adalimumab is a recombinant human monoclonal IgG1 antibody, composed of two kappa light chains and two IgG1 heavy chains, expressed in Chinese Hamster Ovary cells. Interestingly, it is less immunogenic than chimeric mAbs such as infliximab [36]. It recognizes both soluble and membrane-bound TNF- $\alpha$ with high specificity and high affinity $\left(\mathrm{Kd}=6 \times 10^{-10} \mathrm{M}\right)$ and inhibits its biological activity by blocking interaction of TNF- $\alpha$ with p55 and p75 receptors [37]. Adalimumab treatment exerts down-regulation of expression of other pro-inflammatory cytokines, such as IL-6, IL-8 and GMCSF (granulocyte-macrophage colony-stimulating factor) [38]. This antibody has minimised potential side-effects and antigenicity of previous chimeric and humanised mAbs.

\section{Molecular imaging with ${ }^{99 m} T c$-anti-TNF- $\alpha$ mAb (adalimumab)}

Adalimumab was radiolabelled with ${ }^{99 \mathrm{~m}} \mathrm{Tc}$ via an indirect radiolabelling method as described by Abrams et al. [39]. In brief, succinimidyl-hydrazino nicotinamide (S-HYNIC), a bifunctional chelator, was conjugated with native $\mathrm{mAb}$, subsequently, labelling of the conjugated mAb was performed by using tricine as a co-ligand and stannous chloride as a reducing agent. A high labelling efficiency (greater than 95\%) was achieved by using this method. HPLC analysis demonstrated only a minimal release of $<3 \%$ of the radiolabel after $24 \mathrm{~h}$ at $37^{\circ} \mathrm{C}$ [40]. Adalimumab was also radiolabelled with $99 \mathrm{~m}$-technetium by direct method using 2-ME reduction with a high LE (greater the 95\%) [41].

Barrera et al. performed a scintigraphic imaging study in ten patients with active RA to assess the sensitivity and biodistribution of i.v. administered ${ }^{99 \mathrm{~m}}$ Tc-adalimumab [40]. Each patient underwent two scintigraphic examinations, first to assess biodistribution of the radiolabelled antibody and second after 2 weeks to assess specificity for TNF- $\alpha$ targeting and sensitivity for changes in inflammation. Each patient received a sub-therapeutic intravenous dose of $0.1 \mathrm{mg}$ (740 MBq) of ${ }^{99 \mathrm{~m}}$ Tc-anti-TNF- $\alpha \mathrm{mAb}$. Wholebody and joint-specific images were acquired at $5 \mathrm{~min}, 4 \mathrm{~h}$, and $24 \mathrm{~h}$ after administration of the radiopharmaceutical. The results of the first scintigraphy demonstrated that inflamed joints were clearly visualised at 4 and $24 \mathrm{~h}$ after injection and median increased uptake at $24 \mathrm{~h}$ was $30 \%$. However, not all clinically affected joints (particularly small) showed uptake of ${ }^{99 \mathrm{~m}} \mathrm{Tc}$-adalimumab, which may be explained by the absence of this cytokine because TNF- $\alpha$ may not be always present in inflamed joints. Importantly, however, no uptake was seen in normal joints. For the second scintigraphic examination, patients were divided into two groups. One group received a therapeutic dose $(10 \mathrm{mg} / \mathrm{kg})$ of unlabelled anti-TNF- $\alpha \mathrm{mAb}$ immediately before the ${ }^{99 \mathrm{~m}} \mathrm{Tc}$-anti-TNF- $\alpha \mathrm{mAb}$ administration for 
competition study. Another group received an intramuscular injection of corticosteroid $(120 \mathrm{mg}) 2$ days before the second scintigraphy to check the sensitivity to reflect decreased inflammation. Simultaneous injection of unlabelled TNF- $\alpha$ mAb has reduced the joint uptake of ${ }^{99 \mathrm{~m}} \mathrm{Tc}-$ TNF- $\alpha$ mAb by a median of $25 \%$ as a percentage of injected doses after $24 \mathrm{~h}$. This approach has proved the in vivo specificity of this radiolabelled $\mathrm{mAb}$ to target TNF- $\alpha$ in arthritic joints. In another group of patients, systemic corticosteroid administration may reduce the disease activity, which caused decreased uptake of the radiopharmaceutical. This well-designed study clearly demonstrated that this radiopharmaceutical may also be used for the detection of clinically relevant changes in disease activity.

A pilot study was also performed by our group for therapy decision-making and follow-up with $99 \mathrm{~m}$-technetium labelled infliximab and adalimumab mAbs in RA patients [41]. Twelve and nine patients with active RA underwent scintigraphic examination with ${ }^{99 \mathrm{~m}} \mathrm{Tc}$-infliximab and ${ }^{99 \mathrm{~m}}$ Tc-adalimumab, respectively. Imaging was performed before and 3 months after intra-articular therapy with infliximab or systemic therapy with adalimumab. After injection of $370 \mathrm{MBq}{ }^{99 \mathrm{~m}} \mathrm{Tc}$-infliximab or ${ }^{99 \mathrm{~m}} \mathrm{Tc}$-adalimumab, planar anterior and posterior images of arthritic joints were acquired at 6 and $20 \mathrm{~h}$ p.i., and target-tobackground (T/B) ratio was calculated in all affected joints (Fig. 2). In RA patients, no differences of biodistribution were observed between these two radiopharmaceuticals. A variable degree of joint uptake (T/B ratio ranged from 1 to 4 ) has been observed, which was not always correlated with joint pain or swelling. After the therapy with unlabelled antiTNF- $\alpha \mathrm{mAb}$, if the patient demonstrated reduction in the joint uptake of ${ }^{99 \mathrm{~m}} \mathrm{Tc}$-anti-TNF- $\alpha \mathrm{mAb}$, it was also correlated with the reduction of clinical symptoms. Interestingly, patients that showed high pre-therapy uptake had more therapeutic benefit than patients who showed less uptake in the inflamed joints before therapy. Scintigraphic scores assigned to the patients with active RA on the basis of ${ }^{99 \mathrm{~m}} \mathrm{Tc}$-anti-TNF- $\alpha \mathrm{mAb}$ scintigraphy were found to be very reliable for disease monitoring and therapy decision-making. In the same study, we were also able to perform scintigraphy with 99m-technetium labelled non-specific immunoglobulin (HIG) in two patients, to compare it to ${ }^{99 \mathrm{~m}} \mathrm{Tc}-$ anti-TNF- $\alpha$ $\mathrm{mAb}$ scintigraphy for follow-up of the disease activity. ${ }^{99 \mathrm{~m}} \mathrm{Tc}$-HIG scintigraphy was not able to demonstrate the reduction in the joints uptake after the treatment with cold anti-TNF- $\alpha$ mAb, which was confirmed by the clinical data. This study concluded that ${ }^{99 \mathrm{~m}} \mathrm{Tc}-\mathrm{TNF}-\alpha$ antibodies could be used for therapy decision-making in patients with active RA being predictive of success of therapy with same unlabelled $\mathrm{mAb}$.

In both of the above studies, very low (nonpharmacological) doses of the radiolabelled mAbs were used for imaging purposes and no side-effects were observed in any RA patient. However, the complete mechanism of uptake of this radiopharmaceutical has not been revealed until now, means whether these ${ }^{99 \mathrm{~m}} \mathrm{Tc}$-antiTNF- $\alpha$ mAbs target to the membrane bound TNF- $\alpha$ or to the soluble TNF- $\alpha$. Moreover, a comparative analysis of this new technique with conventionally used diagnostic methods for RA, like ultrasound, X-ray and MRI, may provide a rationale for its possible use for early diagnosis and therapy decision-making in RA patients.

\section{Anti-CD20 monoclonal antibody (rituximab)}

Rituximab (Rituxan) was the first chimeric monoclonal antibody approved in 1997 for the treatment of malignancy and recently, in February of 2006, the FDA approved it for the treatment of patients with active RA who do not respond to one or more TNF antagonist therapies. Rituximab is a genetically engineered chimeric murine/human monoclonal antibody to CD20 antigen found on the surface of normal and malignant B lymphocyte [42]. CD20 antigens are involved in production of auto-antibodies, rheumatoid factor (RF), $\mathrm{T}$ cell activation, and proinflammatory cytokine production, and therefore plays an important role in the pathogenesis of RA [43-45]. Rituximab consists of $\mathrm{IgG} 1 \mathrm{~K}$ immunoglobulin containing murine variable and human constant region sequences [42]. Rituximab binds to the CD20 antigen expressed on B lymphocyte with Fab domain, and Fc domain recruits immune effecter functions to mediate B-cell lysis in vitro [46]. Rituximab cytotoxicity is mediated by different mechanisms; ADCC, CDC, direct disruption of signalling pathways and the triggering of apoptosis. These different mechanisms predominate in the treatment of different diseases [47, 48].

\section{Molecular imaging with ${ }^{99 m} T c$-anti-CD20 mAb (rituximab)}

Rituximab was radiolabelled with ${ }^{99 \mathrm{~m}} \mathrm{Tc}$ using a photoactivation method developed by Stalteri et al. [49, 50], and by using a direct radiolabelling method for different inflammatory and autoimmune diseases including RA [51, 52]. Briefly, in the photoactivation method, rituximab was purified from Mabthera solution (Roche) by ultrafiltration using a Centricon YM-10 tube. The same amount of rituximab and Amerscan Medronate II Kit solution (containing medronate, stannous fluoride and p-aminobenzoic acid), were exposed to UV light for $20 \mathrm{~min}$ at $302 \mathrm{~nm}$. Radiolabelling of photo-reduced $\mathrm{mAb}$ was performed by incubating it with ${ }^{99 \mathrm{~m}} \mathrm{Tc}$ at room temperature for $1 \mathrm{~h}$. A high radiolabelling yield of $>95 \%$ was achieved using this method. Under the conditions employed, an average of 4.4 free thiol groups per antibody were obtained, which was 
Fig. 2 Scintigraphic images of wrists of a RA patient injected with ${ }^{99 \mathrm{~m}}$ Tc-adalimumab (anti-TNF- $\alpha \mathrm{mAb}$ ) before (a and $\mathbf{b}$; dorsal images after 6 and $20 \mathrm{~h}$ p.i., respectively) and 3 months after systemic therapy with adalimumab (c and d; dorsal images after 6 and $20 \mathrm{~h}$ p.i., respectively)
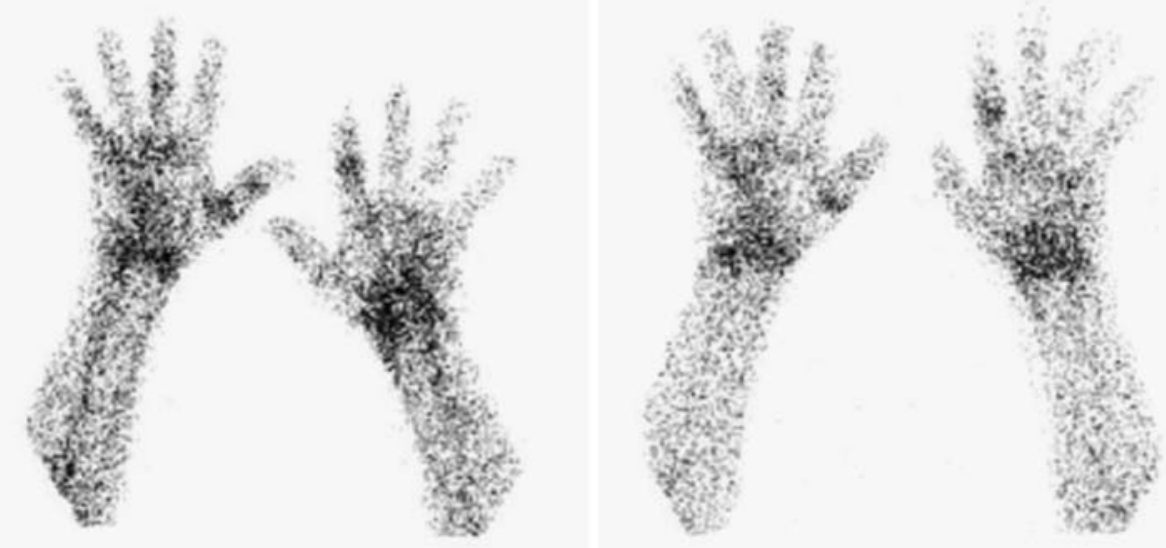

a

b

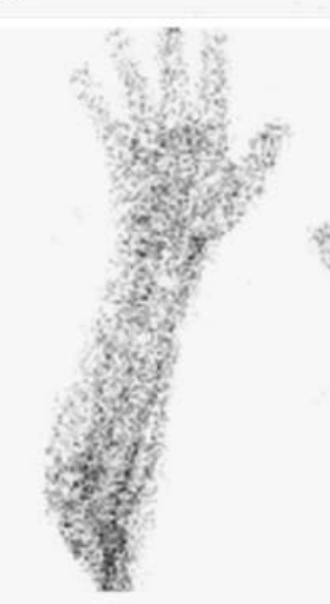

C

less than the total number of available thiol groups in $\mathrm{mAb}$ but sufficient to provide efficient labelling. Rituximab (Mabthera) has also been radiolabelled by direct radiolabelling method with ${ }^{99 \mathrm{~m}} \mathrm{Tc}$ using 2-ME reduction, with a high LE of approximately $95 \%$ and specific activity (3,500-3,700 MBq/mg) [51].

Malviya et al. performed a pilot study in ten patients with different autoimmune diseases including RA, for scintigraphic imaging of $\mathrm{B}$ lymphocytes; all patients underwent immunoscintigraphy before treatment with unlabelled rituximab to assess accumulation in affected joints for possible selection of patients to be treated [52]. In order to test the best time for scintigraphic imaging, whole-body images were acquired 1, 2, 4, 6 and 20 h p.i.; anterior and posterior images of regions of interest were acquired at 6 and $20 \mathrm{~h}$ after injection of $370 \mathrm{MBq}$ of ${ }^{99 \mathrm{~m}}$ Tc-rituximab. No adverse or allergic reactions were observed in patients studied with ${ }^{99 \mathrm{~m}}$ Tc-rituximab. Patients showed rapid and persistent spleen uptake. The best imaging time was obtained at $6 \mathrm{~h}$ p.i., although after $4 \mathrm{~h}$ it was already possible to see accumulations in the inflamed regions that correlated with the clinical data, in particular with DAS28 score. Interestingly, in one patient, when ${ }^{99 \mathrm{~m}} \mathrm{Tc}$ labelled anti-CD20 mAb scintigraphy was compared with anti-TNF$\alpha$ scintigraphy, a different degree of uptake was observed in different joints with either tracer (Fig. 3); this might indicate selective inflammatory pathways in different joints that might benefit from targeted therapies. In conclusion, biological therapies with mAbs may have severe sideeffects and are very expensive; a pre-therapy scintigraphic approach with radiolabelled mAbs for therapy decisionmaking may provide a cost-effective solution. Studies in a larger series of patients are needed to assess the usefulness of this radiopharmaceutical in RA patients.

Anti-CD4 monoclonal antibody

CD4 is a $55-\mathrm{kDa}$ monomeric membrane glycoprotein expressed on $\mathrm{T}$ lineage cells, including majority of thymocytes and a subset of peripheral $\mathrm{T}$ cells and monocytes. The extra-cellular domain of $\mathrm{CD} 4$ binds to the conserved regions of MHC II molecules on antigen-presenting cells (APCs). $\mathrm{CD}^{+} \mathrm{T}$ cells constitute the helper subset that regulates $\mathrm{T}$ and $\mathrm{B}$ cell function during $\mathrm{T}$ cell-dependent responses. $\mathrm{CD} 4^{+} \mathrm{T}$ 
Fig. 3 Scintigraphic images of wrists of a RA patient injected with ${ }^{99 \mathrm{~m}}$ Tc-rituximab

(anti-CD20 mAb) (a and $\mathbf{b}$; after $6 \mathrm{~h}$ p.i. dorsal and ventral images, respectively) and 1 week later scintigraphic images with ${ }^{99 \mathrm{~m}} \mathrm{Tc}$-adalimumab (anti-TNF- $\alpha$ mAb) (c and d; after $6 \mathrm{~h}$ p.i. dorsal and ventral images, respectively), in the same patient. This study clearly indicates that different joints may have a different kind of inflammation and it is therefore desirable to perform a targeted individualised therapy based on scintigraphic evaluation of joint activity

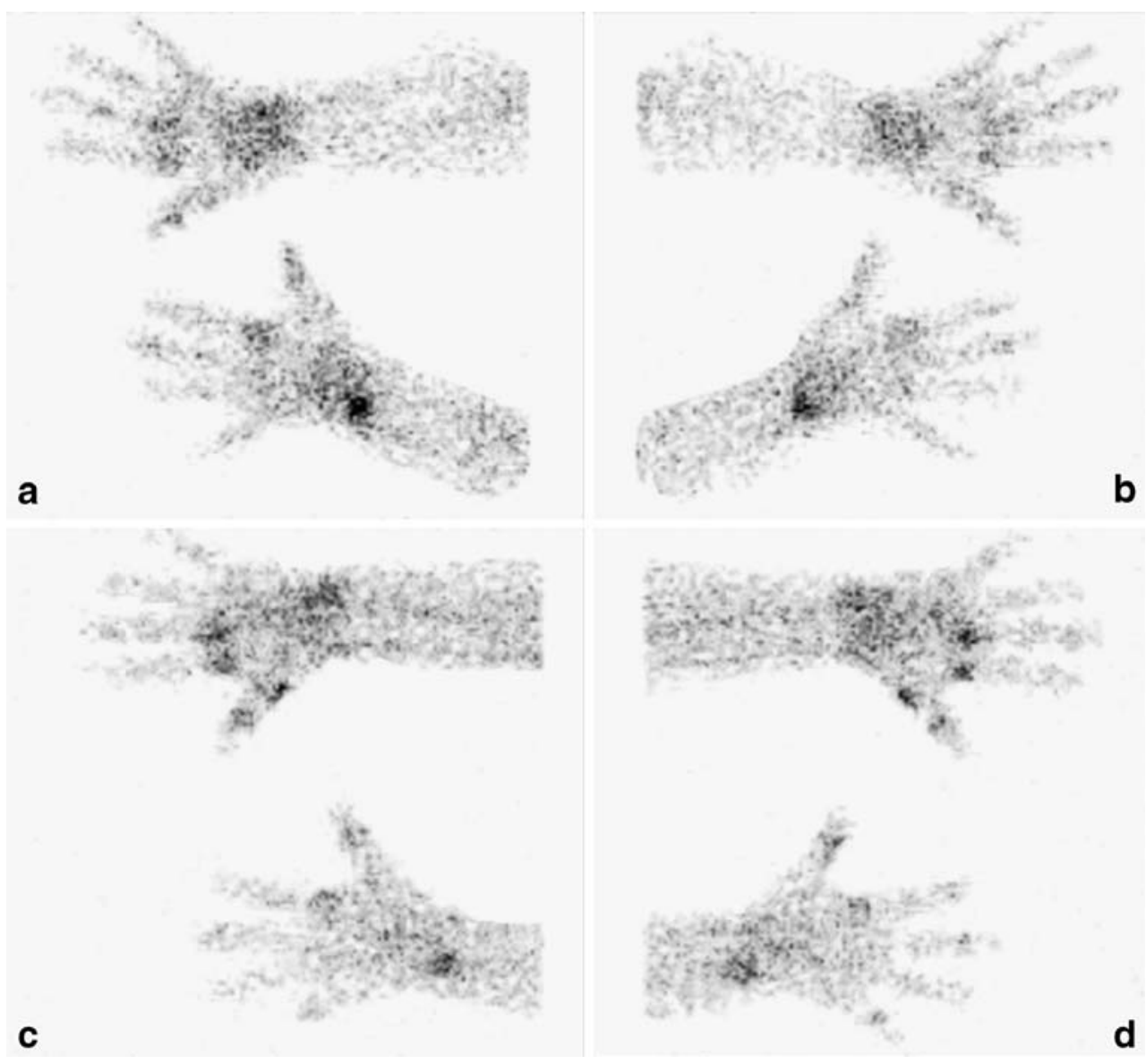

cells and their cytokine products may play an important role in RA [53]. A number of anti-CD4 monoclonal antibodies have been available for the management of RA and other autoimmune disease patients, including murine and primatized anti-CD4 mAbs [54].

Keliximab (IDEC-CE9.1, IDEC) is an IgG1 primatized macaque-human anti-CD4 monoclonal antibody, which reduces the surface density of CD4 and inhibits the CD4-HLA-II interaction to decrease the disease activity in RA [55]. It also causes ADCC of T cells following binding to $\mathrm{Fc} \gamma \mathrm{R}$ that depletes the $\mathrm{CD} 4^{+} \mathrm{T}$ cell population.

Another, chimeric macaque-human anti-CD4, IgG4 $\mathrm{mAb}$, clenoliximab (IDEC-151, IDEC) is similar to keliximab with ablated Fc $\gamma \mathrm{R}$ binding activity. It was developed by substitution of some key amino acids in the constant heavy domain of IgG. Ablation of Fc $\gamma \mathrm{R}$ binding by IgG4 is a critical factor, since in vivo studies have been demonstrated that IgG4 monoclonal antibodies can bind to Fc $\gamma$ RIIIA and induce substantial lymphocyte depletion in patients [56].

\section{Molecular imaging with ${ }^{99 m} T c-C D 4 m A b$}

Anti-CD4 monoclonal antibody was radiolabelled with ${ }^{99 \mathrm{~m}}$ Tc by direct-labelling method using 2-mercaptoethanol reduction. A high labelling efficiency, greater than 95\%, was achieved by using this method. Several studies performed in RA patients using anti-CD4 monoclonal antibody demonstrated its specific targeting in inflamed joints.

A study was performed by Kinne et al. to detect the in vivo specificity of 99m-technetium labelled anti-CD4 mAb to its target molecule. Direct comparison was performed between radiolabelled murine IgG1anti-CD4 specific mAb (MAX.16H5) and non-specific human polyclonal immunoglobulin (HIG) for imaging inflamed joints [57]. Two normal volunteers and eight patients with active or severe RA were intravenously injected with a sub-therapeutic dose of $200-300 \mu \mathrm{g}(370-550 \mathrm{MBq})$ of ${ }^{99 \mathrm{~m}} \mathrm{Tc}-\mathrm{MAX} .16 \mathrm{H} 5$ or $1 \mathrm{mg}(370 \mathrm{MBq})$ of ${ }^{99 \mathrm{~m}} \mathrm{Tc}-\mathrm{HIG}$. Whole-body and jointspecific scintigraphic images were acquired at 1, 4 and $24 \mathrm{~h}$ post-injection. ${ }^{99 \mathrm{~m}} \mathrm{Tc}-\mathrm{CD} 4 \mathrm{mAb}$ demonstrated a higher $\mathrm{T} / \mathrm{B}$ ratio in arthritic joints of RA patients in comparison to ${ }^{99} \mathrm{~m}$ Tc-HIG, just after $4 \mathrm{~h}$ injection. In two patients, an arthroscopic synovectomy of inflamed knee was also performed to obtain synovial tissue. In immunohistological detection, a high number of specific target molecule (macrophages, T-cells) of anti-CD4 mAbs were identified in inflamed synovial membrane of patients. These experiments are an excellent approach for verifying the specific 
binding of radiolabelled anti-CD4 $\mathrm{mAb}$ in the inflamed joint, moreover, on the basis of their data authors concluded that the radiolabelled anti-CD4 $\mathrm{mAb}$ allows more specific detection of inflammatory infiltrates, which are rich in CD4-positive cells. However, authors propose that this radiopharmaceutical may also be used to differentiate chronic joint inflammation from septic arthritis and other joint disorders, because of the fact that anti-CD4 mAb preferentially bind to mononuclear cells infiltrating chronically inflamed joints, but not to granulocytes characteristics of acute inflammation.

Another interesting study was performed by the same authors for the direct comparison of joint-imaging characteristics of inflammation specific and non-specific mAbs in a long-standing severe RA patient [58]. In two scintigraphic examinations, patients received an inflammation-specific 99m-technetium labelled MAX.16H5 (murine IgG1 anti$\mathrm{CD} 4 \mathrm{mAb}$ ) and non-specific 99m-technetium labelled antiCEA (anti-carcinoembryonic) $\mathrm{mAb}$ at a 9-day time interval. Although, for the reasons of diagnosis (anti-CEA mAb) or compatibility (anti-CD4 $\mathrm{mAb}$ ), the doses of the two radiopharmaceuticals were different ( 2 and $0.25 \mathrm{mg}$, respectively). Anterior and posterior whole-body and joint-specific images were acquired at 2, 4 and $24 \mathrm{~h}$ after radiopharmaceutical injection. At all time points, the level of circulating anti-CD4 was lower than the anti-CEA mAb, which causes reduced background activity, providing an improved joint image. Scintigraphic images showed that the uptake was much clearer at $4 \mathrm{~h}$ p.i. of the anti-CD4 mAb in comparison with anti-CEA mAb. In quantitative evaluation at $4 \mathrm{~h}$ p.i. of anti-CD4 $\mathrm{mAb}$, the ratio of average counts/pixel in synovial membrane region to those in adjacent blood vessels was 1.22 , whereas, it was less than $1(0.53)$ in anti-CEA $\mathrm{mAb}$ case. Therefore, this study evidently showed that an inflammation-specific $\mathrm{mAb}$ could undoubtedly allow more specific detection of inflammatory infiltrates in RA.

Becker et al. performed scintigraphy with ${ }^{99 \mathrm{~m}} \mathrm{Tc}$-labelled CD4 specific antibody (MAX.16H5) to study six patients with active and severe RA [59]. Five out of six patients received a sub-therapeutic dose of $200-300 \mu \mathrm{g}$ of ${ }^{99 \mathrm{~m}} \mathrm{Tc}-$ labelled CD4 specific antibody (555 MBq), and three-phase bone imaging was performed. Lymphocytes of one patient were isolated and in vitro labelled with $\mathrm{mAb}$. Seven days prior to radiolabelled $\mathrm{mAb}$ scintigraphy the patients were injected with $555 \mathrm{MBq}$ of 99m-technetium labelled HDP (hydroxymethylendiphosphonic acid) and, early (5 min) and late $(2 \mathrm{~h})$ scans were already performed. In both scans with in vivo and in vitro labelled lymphocytes, anterior and posterior images clearly visualised the inflamed joints at $1.5 \mathrm{~h}$ p.i. and joints showed delineation at 4 to $6 \mathrm{~h}$ p.i. The localisation of diseased joints correlates with clinical signs $(P<0.01)$, early HDP scan $(P<0.01)$ and late bone scan
$(P>0.05)$. Different patterns of joint accumulation, negative late bone scan with high uptake in $\mathrm{mAb}$ scan and high bone scan without positive $\mathrm{mAb}$ scan were observed in patients. However, authors concluded that the ${ }^{99 \mathrm{~m}} \mathrm{Tc}$ labelled CD4 specific antibody can specifically detect diseased joints in patients with active RA and the localisation of diseased joints was superior to with ${ }^{99 \mathrm{~m}} \mathrm{Tc}-\mathrm{HDP}$, because of higher specificity and sensitivity in early joint disease. Moreover, this study demonstrated the possible labelling of human lymphocytes for specific immunoscintigraphic examination, and the method was also comparable with clinical diagnosis.

The above results indeed demonstrate that radiolabelled anti-CD4 mAbs may provide a valuable tool for early and specific diagnosis of the inflamed joints, which could be superior to ${ }^{99 \mathrm{~m}} \mathrm{Tc}-\mathrm{HIG}$ or ${ }^{99 \mathrm{~m}} \mathrm{Tc}-\mathrm{HDP}$ scan, but in this case also the available data is limited by a very low sample size. Further studies are required in a large patient population to verify the efficacy and potential use of this technique in inflammatory disorders.

\section{Anti-E-selectin monoclonal antibody}

E-selectin is an endothelial-specific, cytokine-inducible adhesion molecule [60] that is exclusively expressed on the luminal surface of vascular endothelium during the inflammatory response. Its expression has been demonstrated by immunohistochemistry in a variety of acute and chronic inflammatory diseases, including RA [61]. E-selectin plays a key role in the inflammatory process; it mediates neutrophil, monocyte and eosinophil adhesion to activated vascular endothelium via carbohydrate ligands such as sialyl Lewis X $[62,63]$.

It is well known that the expression of E-selectin on endothelial cells is induced after stimulation by interleukin-1 (IL-1), TNF or lipopolysaccharide. It is not expressed by resting endothelial cells $[64,65]$. Moreover, the increased expression of E-selectin has been detected in several inflammatory disorders $[60,66]$. Therefore, for imaging inflammation in RA, a monoclonal antibody against E-selectin radiolabelled with ${ }^{111}$ In and was successfully tested previously in an animal model [67] and thereafter also in humans $[68,69]$.

\section{Molecular imaging with ${ }^{111}$ In labelled anti-E-selectin $m A b$}

The $\mathrm{F}(\mathrm{ab})_{2}$ fragments of the anti-E-selectin $\mathrm{mAb}$ were generated by pepsin digestion and labelled with ${ }^{111}$ In after diethyltriaminepentaacetic acid (DTPA) coupling. A high labelling efficiency greater than $97 \%$ was achieved by using this method [69].

A comparative study was performed by Jamar et al. between ${ }^{99 \mathrm{~m}} \mathrm{Tc}-\mathrm{HIG}$ (an established tracer for arthritis 
imaging) [70-72] and ${ }^{111}$ In-labelled $1.2 \mathrm{~B} 6\left(\mathrm{~F}\left(\mathrm{ab}^{\prime}\right)_{2}\right.$ fragments of anti-E-selectin $\mathrm{mAb}$ ), in 11 patients with active RA [69]. Each patient underwent ${ }^{99 \mathrm{~m}} \mathrm{Tc}-\mathrm{HIG}$ scintigraphy followed by ${ }^{111}$ In-labelled anti-E-selectin scintigraphy within 5 days. Scintigraphic imaging was performed at 4 and $24 \mathrm{~h}$ post-injection of $555 \mathrm{MBq}$ of ${ }^{99 \mathrm{~m}} \mathrm{Tc}-\mathrm{HIG}$ or $15 \mathrm{MBq}$ of ${ }^{111}$ In-anti-E-selectin. Scintigraphic results were compared with clinical scores of joint involvement. In this study, net ${ }^{111}$ In counts over joints were increased significantly between 4 and $24 \mathrm{~h}$. Using joint tenderness or swelling as an evidence of clinical activity, the sensitivity of ${ }^{111}$ In-anti-E-selectin at 4 and $24 \mathrm{~h}$ was 69 and $82 \%$, respectively, compared to 69 and $62 \%$ for ${ }^{99 \mathrm{~m}} \mathrm{Tc}-\mathrm{HIG}$. Moreover, the images obtained from ${ }^{111}$ In-labelled anti-Eselectin demonstrated much less vascular activity than with ${ }^{99 \mathrm{~m}} \mathrm{Tc}$-labelled non-specific immunoglobulin. This study revealed that radioimmunoscintigraphy using ${ }^{111} \mathrm{In}$-labelled anti-E-selectin is more sensitive, effective and specific than ${ }^{99 \mathrm{~m}} \mathrm{Tc}-\mathrm{HIG}$ scintigraphy to assess RA activity and identify active synovitis. Furthermore, another study published by the same authors demonstrated the significant advantage of using radiolabelled anti-E-selectin (1.2B6) antibody fragment over conventional ${ }^{99 \mathrm{~m}} \mathrm{Tc}-\mathrm{HDP}$ bone scanning to image synovitis [73].

Keelan et al. performed a study with ${ }^{111}$ In-labelled antiE-selectin monoclonal antibody (1.2B6) in an animal model to assess the imaging potential of the antibody [74]. In the pig arthritis model, ${ }^{111} \mathrm{In}-1.2 \mathrm{~B} 6 \mathrm{mAb}$ or ${ }^{111} \mathrm{In}$-control antibody were given intravenously, $3 \mathrm{~h}$ after the intraarticular injection of phytoheamagglutinin (PHA) and the uptake measured by counting the tissues $25 \mathrm{~h}$ post-mortem, which was an excellent approach to direct monitoring of the radioactivity. Scintigraphic images acquired at $24 \mathrm{~h}$ showed localisation of activity in the inflamed knee, and the accumulation of intravenously injected ${ }^{111} \mathrm{In}-1.2 \mathrm{~B} 6 \mathrm{mAb}$ was significantly greater in comparison to that of ${ }^{111} \mathrm{In}$ control antibody. This study demonstrated that ${ }^{111}$ In-anti-Eseletin $\mathrm{mAb}$ specifically accumulates in the synovitis and the authors concluded that radiolabelled anti-E-selectin $\mathrm{mAb}$ could be used to image localised inflammatory tissue.

This scintigraphic methodology has proved to be more reliable than commercially available ${ }^{99 \mathrm{~m}} \mathrm{Tc}-\mathrm{HIG}$ and conventional ${ }^{99 \mathrm{~m}} \mathrm{Tc}-\mathrm{HDP}$ bone scan, and showed potential results for the diagnosis of inflammatory lesions but, unfortunately, no further studies were performed to establish this radiopharmaceutical and this approach remains in the research field only.

\section{Anti-CD3 monoclonal antibody}

A humanised non-FcR binding derivative of the anti-human CD3 monoclonal antibody, OKT3, (hOKT3 $\gamma 1$ [Ala-Ala]), can induce generalised immunosuppression in patients with psoriatic arthritis [75-77]. In this mAb, two additional alanine mutations (amino acids 234, 235) were introduced to prevent FcR binding. The complementarity determining region (CDR) of OKT3 was engrafted onto a human IgG1 backbone, for the low immunogenicity profile. This antibody could cause modulation of the CD3-T-cell receptor complex, induction of clonal anergy and/or induction of regulatory $\mathrm{T}$ cells. Also, theoretically, imaging with ${ }^{99 \mathrm{~m}} \mathrm{Tc}-\mathrm{OKT}-3 \mathrm{mAb}$ is advantageous over ${ }^{99 \mathrm{~m}} \mathrm{Tc}$-anti$\mathrm{CD} 4 \mathrm{mAb}$, since it recognizes $\mathrm{CD} 4^{+}$and $\mathrm{CD} 8^{+}$subtypes of $\mathrm{T}$ lymphocytes, which are both present in the inflamed synovium.

Visilizumab (Nuvion), a new generation of genetically engineered anti-CD3 mAbs, has been developed by grafting murine CDR derived from M291 hybridoma into human non-CDR region of $\operatorname{IgG} 2$ and introducing non-FcR-binding mutations at amino acid residues 234 and 237 (Val $\rightarrow$ Ala) into the $\operatorname{IgG} 2 \mathrm{Fc}$ portion [78-80]. This non-FcR binding humanised $\mathrm{mAb}$ binds with human $\mathrm{CD} 3-\varepsilon$ chain with high specificity and high avidity $\left(\mathrm{Ka}=0.5 \times 10^{9} \mathrm{M}^{-1}\right)$ [81]. An early study has demonstrated that visilizumab induces selective apoptosis of activated $\mathrm{T}$ cells in vitro, but this did not appear in resting $\mathrm{T}$ cells, which may provide therapeutic benefit in several autoimmune diseases [82].

\section{Molecular imaging with ${ }^{99 m}$ Tc labelled anti-CD3 $m A b$}

An anti-CD3 IgG2 murine mAb, muromonab (OKT-3), was labelled with $99 \mathrm{~m}$-technetium by reducing disulphide bonds, a high labelling efficiency (LE) of more than $95 \%$ was assessed by ITLC and HPLC with consistently less than $5 \%$ colloid formation [83].

A study was performed in 7 RA and 2 psoriatic arthritis patients with radiolabelled anti-CD3 $\mathrm{mAb}$ [83]. Anterior and posterior whole body scan and specific regional imaging was commenced $20 \mathrm{~min}$ after the intravenous injection of ${ }^{99 \mathrm{~m}} \mathrm{Tc}-\mathrm{OKT}-3(185 \mathrm{MBq})$. In eight out of nine of these patients, ${ }^{99 \mathrm{~m}} \mathrm{Tc}-\mathrm{OKT}-3$ scans were positive even when potent immunosuppressive and anti-inflammatory drugs induced a good clinical response to pain. The study demonstrated that all 34 joints with moderate to severe pain had moderate to marked uptake of radioactivity. Unexpectedly, two out of a total of nine patients experienced shaking chills, one with associated neck pain, within an hour of radiopharmaceutical infusion. Both cases resolved spontaneously after 20-30 min with or without Benadryl injection. These adverse reactions were surprising, when the injected dose ranging from 5 to $10 \mu \mathrm{g}$ only, which was very less than therapeutic dose (5 mg q.d. for 10-14 days in acute renal transplant rejection). The cause of these adverse reactions could be related to the cytokine release syndrome, which is well described in renal transplanted patients. The authors concluded that ${ }^{99 \mathrm{~m}} \mathrm{Tc}$-anti-CD3 mAb imaging could 
be useful in measuring the therapeutic effectiveness in RA, but the side-effect profile limits the potential use of this radiolabelled $\mathrm{mAb}$ in scintigraphic detection of RA.

Recently, Martins et al. performed a study in 38 patients who met the American College of Rheumatology (ACR) criteria for RA [84], with ${ }^{99 \mathrm{~m}} \mathrm{Tc}$ labelled OKT-3 mAb, but using a different radiolabelling technique than Marcus et al. In this study, the $\mathrm{mAb}$ was labelled using a different chelant and a reductor agent, in place of previously used ascorbic acid reduction method. Each patient received an injection of $185 \mathrm{MBq}(150 \mu \mathrm{g})$ of ${ }^{99 \mathrm{~m}} \mathrm{Tc}-\mathrm{OKT}-3 \mathrm{mAb}$ and all scintigraphic images were acquired at 1 and $3 \mathrm{~h}$ p.i. for $5 \mathrm{~min}$. Two nuclear medicine specialists evaluated scintigraphic scans independently and results were correlated with clinical parameters. Interestingly, no side-effect of this radiolabelled $\mathrm{mAb}$ was observed in any patient. The sideeffect with the same ${ }^{99 \mathrm{~m}} \mathrm{Tc}$ labelled $\mathrm{mAb}$ in the above study therefore could be associated with different radiolabelling method of antibody, but it remains speculative. In this study, ${ }^{99 \mathrm{~m}}$ Tc-OKT-3 uptake demonstrated a significant correlation $(P<0.05)$ with swollen joints, tender joints and the VAS score. Scintigraphic results were also able to follow-up the disease activity in inflamed joints and also correlated with the DAS28 score. Moreover, the study concluded that ${ }^{99 \mathrm{~m}} \mathrm{Tc}-\mathrm{OKT}-3$ is a reliable and objective method for detecting synovial activity and can be used for disease prognosis.

However, as it is well known that a humanised mAb has very less side-effect profile in comparison to a murine or chimeric $\mathrm{mAb}$, therefore, a 99m-technetium labelled humanised anti-CD3 mAb may provide an effective tracer for CD3-positive cell imaging with superior profile. Our group recently radiolabelled visilizumab (Nuvion), with $99 \mathrm{~m}$-technetium by using a hetero bifunctional linker SHNH/S-HYNIC (succinimidyl-6-hydrazinonicotinate hydrochloride) with a high labelling efficiency $(>90 \%)$ and high specific activity $(9,990-11,100 \mathrm{MBq} / \mathrm{mg})$. The in vitro and in vivo results in the animal model demonstrated very potential results for the targeting of $\mathrm{CD} 3$ positive human lymphocytes $[85,86]$. The effectiveness of ${ }^{99 \mathrm{~m}} \mathrm{Tc}$-labelled visilizumab, however, has yet to be checked in humans, but this new radiopharmaceutical may provide a useful tool for in vivo imaging of several immune-mediated inflammations as well as a rationale for therapy with unlabelled anti-CD3 $\mathrm{mAb}$ and follow-up of the disease activity.

New molecules/receptors are regularly identified as possible therapeutic targets and also radiolabelled to generate a radiopharmaceutical that can identify a stagespecific inflammation. The possibility to image in vivo location and quantify extent of these target molecules in inflamed tissues is therefore extremely important in planning an appropriate therapy and to follow-up the efficacy of therapy. Moreover, the radiolabelled $\mathrm{mAb}$ scintigraphy approach may also provide an explanation for the failure of any targeted therapy and/or the justification to select specific targeted therapy for a patient with inflammatory disease. However, these new-generation radiopharmaceuticals still need to be evaluated carefully on a large-scale trial before including in the list of routinely used nuclear medicine tools. Some commercial drug companies, however, are already in the process of preparing commercial kits for scintigraphy with anti-TNF- $\alpha$ antibodies and hopefully these will soon be available on the market.

\section{Concluding remarks}

In this new century we are slowly but continuously shifting to the molecular level of nuclear medicine in the search of high affinity and more specific radiopharmaceuticals. This continuous development has explored a variety of intelligent approaches to establish the foundation of future molecular nuclear medicine imaging modalities. The conventional imaging technique using radiolabelled autologous leukocytes is still the gold standard in nuclear medicine for the diagnosis of infection/inflammation. New multidisciplinary modalities, however, are being developed for more specific diagnostic imaging, targeted molecular therapy, simplicity, cost and safety reasons. These techniques can detect the pathological changes at a very early stage and are helpful in understanding the pathophysiology of different diseases.

Unfortunately, even after numerous studies in the last two decades that proved sensitivity and specificity of a wide range of radiolabelled mAbs for immunoscintigraphy, this useful technique is not used much in clinical practice and until now has remained a research tool inside selected laboratories. The safety profile of murine and chimeric mAbs, unavailability of therapeutic application of mAb in RA patients, and the high cost of therapy were some reasons that have restricted the further development and utilization of immunoscintigraphy in routine clinical practice. Several radiolabelled mAbs (such as anti-E-selectin and anti-CD4) demonstrated their excellent capability for the localization of inflammatory regions, but lack of their use for the therapeutic purposes in RA patients limit their further development and use for immunoscintigraphy. The production of fully human mAbs (such as adalimumab) with no side-effect profile, however, increased the safety profile of immunoscintigraphy and approval of mAbs (such as anti-TNF- $\alpha$ and anti-CD20) for treatment of RA patients also provide us an opportunity to select the patients through this technique.

Previous studies, particularly with radiolabelled polyclonal IgG (HIG), were focused on the detection of the state of activity of the disease; although this is an important 
application, no real clinical advantages have been found compared to other available radiopharmaceuticals with respect to the clinical management of patients.

The real breakthrough in targeted immunoscintigraphy in rheumatoid arthritis activity is the possibility to highlight the presence of the relevant receptors involved in the pathophysiology of the disease directly by means of the specific radiolabelled $\mathrm{mAb}$ that will eventually be used for treatment. To this aim, results obtained so far are highly encouraging and hold promise for therapy decision-making and follow-up, with a view to assessing whether an antibody will accumulate in an inflamed joint before using the same unlabelled antibody for therapeutic purposes. This kind of information can only be obtained with this new imaging approach based on new radiopharmaceuticals that provide a solid basis for the further development and clinical use of immunoscintigraphy in RA.

In the future, we will need to carefully evaluate the clinical role of targeted scintigraphy in RA; different biological treatments are now available and will be developed and we should play a role in selecting the best therapeutic option for the individual patient; if we succeed in doing this, we will not only improve the clinical care of these patients but also prove cost-effective in doing so. It is foreseen that the development of fully human mAbs will further improve the application and development of these techniques, the high costs of clinical developments of experimental radiopharmaceuticals being the major problem to solve.

Acknowledgements GM acknowledges ISORBE (International Society of Radiolabelled Blood Elements) for providing scientific materials for the preparation of this manuscript.

Open Access This article is distributed under the terms of the Creative Commons Attribution Noncommercial License which permits any noncommercial use, distribution, and reproduction in any medium, provided the original author(s) and source are credited.

\section{References}

1. Doran MF, Crowson CS, Pond GR, O'Fallon WM, Gabriel SE. Frequency of infection in patients with rheumatoid arthritis compared with controls: a population-based study. Arthritis Rheum. 2002;46:2287-93.

2. Baecklund E, Ekbom A, Sparén P, Feltelius N, Klareskog L. Disease activity and risk of lymphoma in patients with rheumatoid arthritis: nested case-control study. BMJ. 1998;317:180-1.

3. Solomon DH, Karlson EW, Rimm EB, Cannuscio CC, Mandl LA, Manson JE, et al. Cardiovascular morbidity and mortality in women diagnosed with rheumatoid arthritis. Circulation. 2003;107:1303-7.

4. Wolfe F, Freundlich B, Straus WL. Increase in cardiovascular disease prevalence in rheumatoid arthritis. J Rheumatol. 2003;30:36-40.

5. Thomas E, Brewster DH, Black RJ, Macfarlane GJ. Risk of malignancy among patients with rheumatic conditions. Int $\mathrm{J}$ Cancer. 2000;88:497-502.
6. Wolfe F, Mitchell DM, Sibley JT, Fries JF, Bloch DA, Williams CA, et al. The mortality of rheumatoid arthritis. Arthritis Rheum. 1994:37:481-94.

7. Landewé RB, Boers M, Verhoeven AC, Westhovens R, van de Laar MA, Markusse HM, et al. COBRA combination therapy in patients with early rheumatoid arthritis: long-term structural benefits of a brief intervention. Arthritis Rheum. 2002;46 (2):347-56

8. Gabriel SE, Crowson CS, Kremers HM, Doran MF, Turesson C, O'Fallon WM, et al. Survival in rheumatoid arthritis: a populationbased analysis of trends over 40 years. Arthritis Rheum. 2003;48:54-8.

9. O'Dell JR, Haire CE, Erikson N, Drymalski W, Palmer W, Eckhoff PJ, et al. Treatment of rheumatoid arthritis with methotrexate, sulphasalazine and hydroxychloroquine, or a combination of these medications. New Engl J Med. 1996;334:1287-91.

10. Landewè RB, Boers M, Verhoeven AC, Westhovens R, van de Laar MA, Markusse HM, et al. COBRA combination therapy in patients with early rheumatoid arthritis: long-term structural benefits of a brief intervention. Arthritis Rheum. 2002;46(2):347-56.

11. Choy EH, Kingsley GH, Panayi GS. Monoclonal antibody therapy in rheumatoid arthritis. Br J Rheumatol. 1998;37:484-90.

12. Fan PT, Leong KH. The use of biological agents in the treatment of rheumatoid arthritis. Ann Acad Med Singapore. 2007;36:128-34.

13. Chianelli M, D'Alessandria C, Conti F, Priori R, Valesini G, Annovazzi A, et al. New radiopharmaceuticals for imaging rheumatoid arthritis. Q J Nucl Med Mol Imaging. 2006;50:217-25.

14. Kohler G, Milstein C. Continuous cultures of fused cells secreting antibody of predefined specificity. Nature. 1975;256:495-97.

15. Brekke OH, Sandlie I. Therapeutic antibodies for human diseases at the dawn of the twenty-first century. Nat Rev Drug Discov. $2003 ; 2: 52-62$.

16. Aksentijevich I, Flinn IW. Monoclonal antibody therapy with autologous peripheral blood stem cell transplantation for nonHodgkin's lymphoma. Cancer Control. 2002;9(2):99-105.

17. Morrison SL, Johnson MJ, Herzenberg LA, Oi VT. Chimeric human antibody molecules: mouse antigen-binding domains with human constant region domains. Proc Nat Acad Sci. 1984;81:6851-5.

18. Hanauer SB. Safety of infliximab in clinical trials. Aliment Pharmacol Ther. 1999;13:16-22.

19. Brekke OH, Sandlie I. Therapeutic antibodies for human diseases at the dawn of the twenty-first century. Nat Rev Drug Discov. 2003;2:52-62.

20. Jones PT, Dear PH, Foote J, Neuberger MS, Winter G. Replacing the complementarity-determining regions in a human antibody with those from a mouse. Nature. 1986;321:522-5.

21. Holmes MA, Buss TN, Foote J. Conformational correction mechanisms aiding antigen recognition by a humanized antibody. J Exp Med. 1998;187:479-85.

22. Mascheretti S, Schreiber S. The role of pharmacogenomics in the prediction of efficacy of anti-TNF therapy in patients with Crohn's disease. Pharmacogenomics. 2004;5(5):479-86.

23. Hoogenboom HR. Selecting and screening recombinant antibody libraries. Nat Biotechnol. 2005;23:1105-16.

24. Lonberg N. Human antibodies from transgenic animals. Nat Biotechnol. 2005;23:1117-25.

25. Trikha M, Yan L, Nakada MT. Monoclonal antibodies as therapeutics in oncology. Curr Opin Biotechnol. 2002;13:609-14.

26. Weir AN, Nesbitt A, Chapman AP, Popplewell AG, Antoniw P, Lawson AD. Formatting antibody fragments to mediate specific therapeutic functions. Biochem Soc Trans. 2002;30:512-16.

27. Kaushik VV, Moots RJ. CDP-870 (Certolizumab) in rheumatoid arthritis. Expert Opin Biol Ther. 2005;5(4):601-6.

28. Knight DM, Trinh H, Le J, Siegel S, Shealy D, McDonough M, et al. Construction and initial characterization of a mouse-human chimeric anti-TNF antibody. Mol Immunol. 1993;30:1443-53. 
29. Scallon BJ, Moore MA, Trinh H, Knight DM, Ghrayeb J. Chimeric anti-TNF- $\alpha$ monoclonal antibody $\mathrm{cA} 2$ binds recombinant transmembrane TNF- $\alpha$ and activates immune effector functions. Cytokine. 1995; 7:251-59.

30. Scott DL, Kingsley GH. Tumor necrosis factor inhibitors for rheumatoid arthritis. N Eng J Med. 2006;355:704-12.

31. ten Hove T, van Montfrans C, Peppelenbosch MP, van Deventer SJ. Infliximab treatment induces apoptosis of lamina propria $\mathrm{T}$ lymphocytes in Crohn's disease. Gut. 2002;50:206-11.

32. Siegel SA, Shealy DJ, Nakada MT, Le J, Woulfe DS, Probert L, et al. The mouse/human chimeric monoclonal antibody cA2 neutralizes TNF in vitro and protects transgenic mice from cachexia and TNF lethality in vivo. Cytokine. 1995;7:15-25.

33. Barone D, Krantz C, Lambert D, Maggiora K, Mohler K. Comparative analysis of the ability of Etanercept and infliximab to lyse TNF-expressing cells in a complement dependent fashion. Arthritis Rheum. 1999;42(Suppl):S90.

34. Annovazzi A, D’Alessandria C, Caprilli R, Viscido A, Corsetti F, Parisella MG, et al. Radiolabelling of a monoclonal anti-TNF- $\alpha$ antibody with ${ }^{99 \mathrm{~m}} \mathrm{Tc}$ : in vitro studies. Q J Nucl Med Mol Imaging. 2002;46(Suppl 1):27.

35. Conti F, Priori R, Chimenti MS, Coari G, Annovazzi A, Valesini $G$, et al. Successful treatment with intraarticular infliximab for resistant knee monarthritis in a patient with spondylarthropathy: a role for scintigraphy with ${ }^{99 \mathrm{~m}} \mathrm{Tc}$-infliximab. Arthritis Rheum. 2005;52(4):1224-26.

36. Anderson PJ. Tumor necrosis factor inhibitors: clinical implications of their different immunogenicity profiles. Semin Arthritis Rheum. 2005;34(Suppl):19-22.

37. Rau R. Adalimumab (a fully human anti-tumour necrosis factor a monoclonal antibody) in the treatment of active rheumatoid arthritis: the initial results of five trials. Ann Rheum Dis. 2002;61(Suppl II):70-3.

38. Adalimumab (Humira). European Public Assessment Report Scientific Discussion. http://www.emea.europa.eu/humandocs/ PDFs/EPAR/humira/Humira-H-481-II-43-AR.pdf (assessed on 01.07.08).

39. Abrams MJ, Juweid M, tenKate CI, Schwartz DA, Hauser MM, Gaul FE, et al. Technetium-99m-human polyclonal IgG radiolabelled via the hydrazino nicotinamide derivative for imaging focal sites of infection in rats. J Nucl Med. 1990;31:2022-8.

40. Barrera P, Oyen WJ, Boerman OC, van Riel PL. Scintigraphic detection of tumour necrosis factor in patients with rheumatoid arthritis. Ann Rheum Dis. 2003;62:825-8.

41. Malviya G, D’Alessandria C, Lanzolla T, Lenza A, Conti F, Valesini $\mathrm{G}$, et al. ${ }^{99 \mathrm{~m}}$ Technetium labelled anti-TNF- $\alpha$ antibodies for the therapy-decision making and follow-up of patients with rheumatoid arthritis. Q J Nucl Med Mol Imaging. 2008;52(Suppl 1(2)):13-4.

42. Rituxan ${ }^{\circledR}$ (Rituximab), package insert. Genentech Inc., San Francisco, CA; revised September, 2008. http://www.gene.com/ gene/products/information/pdf/rituxan-prescribing.pdf (assessed on $02 / 10 / 08$ ).

43. Stashenko P, Nadler LM, Hardy R, Schlossman SF. Characterization of a human B lymphocyte-specific antigen. J Immunol. 1980;125:1678-85.

44. Tedder TF, Boyd AW, Freedman AS, Nadler LM, Schlossman SF. The B cell surface molecule B1 is functionally linked with B-cell activation and differentiation. J Immunol. 1985;135(2):973-9.

45. Dorner T. Rumester, G. The role of B-cells in rheumatoid arthritis: mechanisms and therapeutic targets. Curr Opin Rheumatol. 2003;15:246-52.

46. Reff ME, Carner K, Chambers KS, Chinn PC, Leonard JE, Raab $\mathrm{R}$, et al. Depletion of B cells in vivo by a chimeric mouse human monoclonal antibody to CD20. Blood. 1994;83:435-45.

47. Johnson PW, Glennie MJ. Rituximab: mechanisms and applications. Br J Cancer. 2001;85:1619-23.
48. Olszewski AJ, Grossbard ML. Empowering targeted therapy: lessons from Rituximab. Sci STKE. 2004;2004(241):30.

49. Stopar TG, Mlinaric-Rascan I, Fettich J, Hojker S, Mather SJ. ${ }^{99 m}$ Tc-rituximab radiolabelled by photo-activation: a new nonHodgkin's lymphoma imaging agent. Eur J Nucl Med. 2006;33:53-9.

50. Stalteri MA, Mather SJ. Technetium-99m labelling of the antitumour antibody PR1A3 by photoactivation. Eur J Nucl Med. 1996;23:178-87.

51. Wang $\mathrm{XJ}$, Lin $\mathrm{BH}$, Yang $\mathrm{Z}$, Ouyang $\mathrm{T}$, Li JF, $\mathrm{Xu} \mathrm{B}$, et al. Preliminary study on a new sentinel lymphoscintigraphy agent ${ }^{99 m}$ Tc-Rituximab for breast patient. Zhonghua Zhong Liu Za Zhi (Chinese J Oncol). 2006;28(3):200-3.

52. Malviya G, Laganà B, Milanetti F, Del Mastro C, Familiari D, Dierckx RA, et al. Use of 99m-technetium labelled Rituximab for imaging of patients with chronic inflammatory diseases. Eur J Nucl Med Mol Imaging. 2008;35(Suppl 2):S142.

53. Pohlers D, Schmidt-Weber CB, Franch A, Kuhlmann J, Bräuer R, Emmrich F, et al. Differential clinical efficacy of anti-CD4 monoclonal antibodies in rat adjuvant arthritis is paralleled by differential influence on NF-kB binding activity and TNF- $\alpha$ secretion of T cells. Arthritis Res. 2002;4:184-89.

54. Reddy MP, Kinney CAS, Chaikin MA, Payne A, Fishman-Lobell $\mathrm{J}$, Tsui $\mathrm{P}$, et al. Elimination of $\mathrm{Fc}$ receptor-dependent effector functions of a modified IgG4 monoclonal antibody to human CD4. J Immunol. 2000;164:1925-33.

55. Mason U, Aldrich J, Breedveld F, Davis CB, Elliott M, Jackson $\mathrm{M}$, et al. CD4 coating, but not CD4 depletion, is a predictor of efficacy with primatized monoclonal anti-CD4 treatment of active rheumatoid arthritis. J Rheumatol. 2002;29:220-29.

56. Isaacs JD, Wing MG, Greenwood JD, Hazleman BL, Hale G, Waldmann H. A therapeutic human IgG4 monoclonal antibody that depletes target cells in humans. Clin Exp Immunol. 1996; 106:427-33.

57. Kinne RW, Becker W, Schwab J, Horneff G, Schwarz A, Kalden $\mathrm{JR}$, et al. Comparison of 99Tcm-labelled specific murine anti-CD4 monoclonal antibodies and nonspecific human immunoglobulin for imaging inflamed joints in rheumatoid arthritis. Nucl Med Commun. 1993;14(8):667-75.

58. Kinne RW, Becker W, Schwab J, Schwarz A, Kalden JR, Emmrich $F$, et al. Imaging rheumatoid arthritis joints with technetium-99m labelled specific anti-CD4- and non-specific monoclonal antibodies. Eur J Nucl Med. 1994;21:176-80.

59. Becker W, Emmrich F, Horneff G, Burmester G, Seiler F, Schwarz A, et al. Imaging rheumatoid arthritis specifically with technetium 99m CD4-specific (T-helper lymphocytes) antibodies. Eur J Nucl Med. 1990;17(3-4):156-9.

60. Bevilacqua MP. Endothelial-leukocytes adhesion molecules. Ann Rev Immunol. 1993;11:767-804.

61. Mason JC, Haskard DO. The clinical importance of leucocytes and endothelial cell adhesion molecules in inflammation. Vasc Med Rev. 1994;5:249-75.

62. Bevilacqua MP, Stengelin S, Gimbrone MA Jr, Seed B. Endothelial leucocyte adhesion molecule-1: an inducible receptor for neutrophils related to complement proteins and lectins. Science. 1989;243:1160-65.

63. Bhushan M, Bleiker TO, Ballsdon AE, Allen MH, Sopwith M, Robinson MK, et al. Anti-E-selectin is ineffective in the treatment of psoriasis: a randomized trial. Br J Dermatol. 2002;146:824-31.

64. Pober JS, Bevilacqua MP, Mendrik DL, Lapierre LA, Fiers W, Gimborn MA Jr. Two distinct monokines, interleukin 1 and tumor necrosis factor, each in dependently induce biosynthesis and transient expression of the antigen on the surface of cultured human vascular endothelial cells. J Immunol. 1986;136:1680-87.

65. Wellicome SM, Thornhill MH, Pitzalis C, Thomas DS, Lanchbury JS, Panayi GS, et al. A monoclonal antibody that detects a novel 
antigen on endothelial cells that is induced by tumor necrosis factor, IL-1 or lipopolysaccharide. J Immunol. 1990;144:2558-65.

66. Bevilacqua MP, Nelson RM. Selectins. J Clin Invest. 1993;91:379-87.

67. Jamar F, Chapman PT, Harrison AA, Binns RM, Haskard DO, Peters AM. Inflammatory arthritis: imaging of endothelial cell activation with an indium-111-labelled $\mathrm{F}(\mathrm{ab}$ ')2 fragment of antiE-selectin monoclonal antibody. Radiology. 1995;194:843-50.

68. Chapman PT, Jamar F, Keelan ET, Peters AM, Haskard DO. Use of monoclonal antibody against E-selectin for imaging endothelial activation in rheumatoid arthritis. Arthritis Rheum. 1996; 39:1371-75.

69. Jamar F, Chapman PT, Manicourt D-H, Glass DM, Haskard DO, Peters AM. A comparison between ${ }^{111}$ In-anti-E-selectin $\mathrm{mAb}$ and ${ }^{99} \mathrm{Tc}^{\mathrm{m}}$-labelled human non-specific immunoglobulin in radionuclide imaging of rheumatoid arthritis. Brit J Radiol. 1997;70:47381 .

70. van der Lubbe PA, Arndt JW, Calame W, Ferreira TC, Pauwels EK, Breedveld FC. Measurement of synovial inflammation in rheumatoid arthritis with technetium-99m labelled human polyclonal immunoglobulin G. Eur J Nucl Med. 1991;18:119-23.

71. de Bois MH, Arndt JW, van der Velde EA, van der Lubbe PA, Westedt ML, Pauwels EK, et al. ${ }^{99 \mathrm{~m}}$ Tc-human immunoglobulin scintigraphy- a reliable method to detect joint activity in rheumatoid arthritis. J Rheumatol. 1992;19:1371-6.

72. Liberatore M, Clemente M, Iurilli AP, Zorzin L, Marini M, Di Rocco E, et al. Scintigraphic evaluation of disease activity in rheumatoid arthritis: a comparison of technetium-99m human non-specific immunoglobulins, leucocytes and albumin nanocolloids. Eur J Nucl Med. 1992;19:853-57.

73. Jamar F, Houssiau FA, Devogelaer J-P, Chapman PT, Haskard DO, Beaujean V, et al. Scintigraphy using a technetium $99 \mathrm{~m}-$ labelled anti-E-selectin $\mathrm{Fab}$ fragment in rheumatoid arthritis. Rhematol. 2002;41:53-61

74. Keelan ETM, Harrison AA, Chapman PT, Binns RM, Peters AM, Haskard DO. Imaging vascular endothelial activation: an approach using radiolabelled monoclonal antibodies against the endothelial cell adhesion molecule E-selectin. J Nucl Med. 1994;35:276-81.
75. Utset TO, Auger JA, Peace D, Zivin RA, Xu D, Jolliffe L, et al. Modified anti-CD3 therapy in psoriatic arthritis: a phase I/II clinical trial. J Rheumatol. 2002;29:1907-13.

76. Alegre ML, Peterson LJ, Xu D, Sattar HA, Jeyarajah DR, Kowalkowski K, et al. A non-activating "humanized" anti-CD3 monoclonal antibody retains immunosuppressive properties in vivo. Transplantation. 1994;57:1537-43.

77. Woodle ES, Xu D, Zivin RA, Auger J, Charette J, O'Laughlin R, et al. Phase I trial of a humanized, Fc receptor nonbinding OKT3 antibody, huOKT3 $\gamma 1$ (Ala-Ala) in the treatment of acute renal allograft rejection. Transplantation. 1999;68:608-16.

78. Cole MS, Stellrecht KW, Shi JD, Homola M, Hsu DH, Anasetti C, et al. HuM291, a humanized anti-CD3 antibody, is immunosuppressive to $\mathrm{T}$ cells while exhibiting reduced mitogenicity in vitro. Transplantation. 1999;68(4):563-71.

79. Routledge EG, Falconer ME, Pope H, Lloyd IS, Waldmann H. The effect of aglycosylation on the immunogenicity of a humanized therapeutic CD3 monoclonal antibody. Transplantation. 1995;60(8):847-53.

80. Cole M, Anasetti C, Tso JY. Human IgG2 variants of chimeric anti-CD3 are non-mitogenic to T cells. J Immunol. 1997;159:361321.

81. Trajkovic V. Nuvion Protein Design Labs. Curr Opin Investig Drugs. 2002;3(3):411-4.

82. Dingermann T, Zündorf I. Macromolecular immunosuppressants. Biotechnol J. 2006;1:47-57.

83. Marcus C, Thakur ML, Huynh TV, Louie JS, Leibling M, Minami $\mathrm{C}$, et al. Imaging rheumatic joint diseases with anti-T lymphocyte antibody OKT-3. Nucl Med Commun. 1994;15(10):824-30.

84. Martins FPP, Gutfilen B, De Souza SAL, De Azevedo MNL, Cardoso LR, Fraga R, et al. Monitoring rheumatoid arthritis synovitis with ${ }^{99 \mathrm{~m}} \mathrm{Tc}$-anti-CD3. Brit J Radiol. 2008;81:25-9.

85. Malviya G, De Vries EFJ, Dierckx RA, Signore A. Radiopharmaceuticals for imaging chronic lymphocytic inflammation. Bra Arch Bio Tech. 2007;50:1-13.

86. Malviya G, D'Alessandria C, Trotta C, Massari R, Soluri A, Scopinaro F, et al. Radiolabeled-Visilizumab, a humanized antiCD3 monoclonal antibody, for in vivo targeting of human CD3+ lymphocytes. Eur J Nucl Med Mol Imaging. 2008;35(Suppl 2):S142. 